\title{
LOS NO VISIBLES: LATINOAMÉRICA EN LATENCIA
}

El rico y el pobre ¿no son hermanos? Si, y el hermano rico es Caín.

Un mapamundi que no comprenda la utopía No es digo de ser mirado. Oscar Wilde.

Manizales, 2009-11-02 (Rev. 2009-11-25)

Las relaciones sociales de producción y reproducción están cambiando en el mundo de la globalización alternativa. La diversificación de la producción, la precaria condición del empleo y la generación de bloques comerciales extractivos, asesinos de las poblaciones, ha engendrado en su interior diversidades de políticas culturales, con asiento en lo nativo-ancestral y la tierra madre, ha parido redes de movimientos y bloques de territorios anticapitalistas, contrahegemónicos, han puesto la cara y enfrentado al engaño y la expoliación mediante un modo de producción rural y urbano inclusivo, respetuoso del medio natural y humano y con grados de hermandad y cohesión que se creían perdidos en los nodos y las islas de la producción posindustrial.

En Colombia, punto al norte de Suramérica, se desesperanza la identidad. En el Paraguay, ruta al sur que abraza el tres de la triple frontera, el campo se despuebla de biodiversidad humana y no humana, mientras el relacionamiento social, afectivo y emotivo, laboral y racional, se convierte en intercambio impersonal e individualizante, utilitario. Casi que como regla, y volviendo al punto norte, las seguridades de las ciudades y el campo están al lado de una "justicia" por mano propia, contratada, conservadurizada, puesta a la derecha, donde un eterno presente quiere aplastar las imaginaciones, la amistad y la solidaridad humana.

En México (su borde sur, bien adentro en Chiapas), punto norte latinoamericano y Bolivia, núcleo al centro de Suramérica, se recrean territorios donde emerge con olor a tierra, flores, leña y capuchas, la voz de una garganta ahogada por siglos, una sangre que abonó el suelo con su sangre, y un canto que es fruto del árbol más alto. Territorios "donde otro mundo es posible", territorios de globalidad de expresiones, de pueblos dentro de muchos pueblos: entonces se amanece en la mente con el sentir de un futuro distinto, alternativo, donde el dinero no es el medio del intercambio universal y el desarrollo capitalista encuentra a la solidaridad como factor de movimiento, de intercambio, de cosmogonía ${ }^{1}$.

\section{BOLIVIA Y MÉXICO: dos mitos de fundación hechos política de reconocimiento}

Aimaras, Mayas, Quechuas, descendientes de Tupac Amaru, de Zapata, de Tupac Katari y del Che Guevara, nuevos dioses de un Panteón guerrero y sempiterno, convertidos en símbolo de identidad de una Latinoamérica que ha tenido que borrar al dios capital para refundar territorios y revivir a los hombre libres en medio de la guerra y la precariedad del sustento.

Siglos de invisibilidad y décadas de falta de voz y voto que hable y decida el destino de la nación, se transforma hoy en el nacimiento de la palabra, en una relación donde religiosidad-rito-ceremonia-historia colectiva fundamentan y entregan horizonte a la política, entregan sentido al religare, se une lo que estaba disperso y se reforma lo deformado. Hay un nuevo mundo representado en micro-mundos donde la razón económica y de la ciencia aplicada da un paso atrás frente a la emergencia de la política como ejercicio de la religión en donde los dioses de la agricultura caminan a la ciudad con los pasos descalzos, rebeldes, sumados a la revolución de las ideas, en medio de una organización tan compleja como tradicional y al lado de este nuevo tiempo.

Las redes de organización logran una coordinación que ha tenido que llevar más de 500 años en extenderse por la tierra toda, en forma de mensaje de radio, de grafiti en las paredes de las grandes capitales, de mediación comunicante del discurso, con las armas del viejo sistema, con las nuevas palabras y expresiones ceremoniales que ya no se perderán por el empeño de los antiguos súbditos, con banderas ondeantes que se mueven por América, con pasos que no renuncian, acompañados todos de la obediencia al comandante: el pueblo que planea en el horizonte. Así resulta una nueva manera de pensar los conceptos de la política y la organización, donde se utiliza lo socio-territorial como bandera de lucha, mediante el aprovechamiento del saber jurídico de occidente y de los pueblos ancestrales, para organizar gobiernos en los que los pueblos se hacen hermanos y dejan de ser dominios de una 
clase, de una casta; impera una política cultural de defensa de los recursos y de los ecosistemas, una mirada biocéntrica de las plantas, los animales, el hombre y la mujer, una identidad y una cosmovisión en medio de "los caracoles", del otrora Don Antonio, de los llamados a la señorita sociedad civil, para alcanzar una universalidad del movimiento colectivo, una lucha por la orientación y el significado del territorio, con el rostro - a veces- de frente, con capuchas, pañoletas, banderas de mil colores, en la ruta por la emancipación.

La defensa de los ecosistemas, de los genes, de los recursos que el universo físico y simbólico provee es hoy la bandera (a veces pacífica, a veces contestataria y de fuerza, a veces local, global, intermitente) mediante la cual se resignifica el movimiento latinoamericano, el cual encuentra despertares en el MAS, en el EZLN, en el MST, en Vía Campesina, en Pachacutic, en las Comunidades de Paz, en los Piqueteros, en ONIC, en Antiautoritarios y Antitaurinos, en Libertarios, en Comunistas, en Liberales, Cocaleros, Corteros, Chacareros, Aparceros, Colonos, Waorany, Paeces, Koguis, Comunidades Negras, y en un sinfín de organizaciones que mantienen la palabra y la resistencia para un buen porvenir.

La diversidad de resistencias en la sujeción a la tierra, la diversidad de semillas, de formas de arado, de maneras de intercambiar lo producido colectivamente, alimentado provisiones para la vida humana y la felicidad en contra de la semilla única y mutada, del trabajo esclavo, de la gran extensión egoísta, de la "soberanía violada", del grito callado, de la concentración y el monopolio; la diversidad de resistencias en la lucha por la decisión autónoma, por el "ecoconocimiento", por la memoria. Escupitajo al agronegocio y al glifosato, escupitajo a la perpetuación de la especie en las más precarias condiciones. Escupitajo a los escuadrones de la muerte, a los narco-para-terratenientes, a los subsidios para los grandes propietarios. En América Latina se cuenta con generaciones de nuevos sujetos, de buenos hijos, para alcanzar un futuro alternativo y desde el Sur que haga al Leviatán del Norte comerse sus propias entrañas.

Paulo César Giraldo Betancur Sociólogo

Universidad de Caldas

1. La fuerza y brillantez de los indígenas, afrodescendientes y campesinos en Colombia ya dirá de otro mundo posible en estas tierras de olvido, tierra arrasada, "pedagogía del terror" y resistencia. 